\title{
Margin Call in Islamic Finance
}

\author{
Ahmet Suayb Gundogdu ${ }^{1}$ \\ ${ }^{1}$ International Islamic Trade Finance Corporation, Islamic Development Bank, Jeddah, Saudi Arabia \\ Correspondence: Ahmet Suayb Gundogdu, International Islamic Trade Finance Corporation. Islamic \\ Development Bank PO Box 5925 Jeddah 21432, Saudi Arabia. Tel: 966-12-646-8265. E-mail: \\ agundogdu@isdb.org
}

Received: January 13, 2014

Accepted: July 16, 2014

Online Published: July 25, 2014

doi:10.5539/ijef.v6n8p205

URL: http://dx.doi.org/10.5539/ijef.v6n8p205

\begin{abstract}
Murabaha, the most popular Islamic finance contract, has been subject of many studies. In its simplest form it is buying and selling with profit and has two forms: Asset based and Asset backed. Upto now, there are many studies on asset based Murabaha sale, which consist of buying a product and selling, transferring ownership, to loan seeker simultaneously in exchange of debt obligation. With this structure asset based Murabaha has been subject of much criticism. This article introduces the concept of asset backed Murabaha sale, by which financier holds the title of product until final sale to loan seeker, from a case of sugar structured trade commodity financing. In addition to discussion of general risk issues, special focus on commodity price risk management: margin calculation and margin call methods proposed so that Islamic finance industry can manage asset backed Murabaha contract without recourse to additional security of bank guarantee, mortgages, etc. or disallowed, by Islam, derivative based commodity price hedging products.
\end{abstract}

Keywords: Islamic finance, margin call, trade finance, structured commodity trade finance, commodity price risk management

\section{Murabaha Sale: Asset Based or Asset Backed}

The purpose of this article is to address some aspect of one of the most controversial area of Islamic Finance: Murabaha sale. There are many studies which explain Murabaha sale of deferred profit sale. Murabaha has been matured with "FAS-2: Murabaha and Murabaha to the Purchase Orderer" standard developed by Accounting and Auditing Organization for Islamic Financial Institutions. Nevertheless, as widely practiced, asset based Murabaha has been subject of much criticism (Ahmad, 2010; Yousef 2004) (Note 1). Asset based Murabaha is a simultaneous purchase and sale by Islamic financial institution which transfer ownership to borrower upon completion of process. Since ownership does not stay with Islamic financial institutions, but, transferred to borrower in exchange of fixed return repayment obligation, asset based Murabaha has been subject of following criticism.

i. Debt Creation: In case of asset based Murabaha sale, transfer of ownership is simultaneous from supplier to financier and from financier to loan seeker. Presentation of invoice and/or shipping document would assure the genuine transaction but as highlighted by Yousef (2004) it is argued that Islamic finance should be based on profit-risk sharing principles. Hence, debt obligation creation in asset based Murabaha, as argued, would yield similar result of conventional finance.

ii. Mark-up Feature: In case of asset based Murabaha, loan seeker intimate its request with form of offer, asking purchase of certain goods from lender, and commit itself for purchasing the same from lender with pre-determined mark-up. In exchange lender, with form of acceptance, commits itself to transaction. Again some argue that Islamic finance should be based on profit-risk sharing rather than fixed return arrangements. Another aspect of mark-up is late payment charges. Islamic financial instructions are not allowed to charge any additional mark-up after date of maturity in case of delay in repayments by borrower. However, some Islamic banks started to impose such late payment charges which would effectively convert Islamic finance to conventional.

iii. Collateral: like conventional financial institutions, Islamic banks very often ask for collateral in the form of mortgage, guarantees, etc. to assure timely repayment of debt created out of Murabaha sale. This again is another source of criticism. 
iv. Risk and Agency: Islamic banks, like conventional banks, would avoid quality issues related to goods financed. Asset based Murabaha contracts are designed to appoint loan seeker as undisclosed agent of bank to conclude purchase contract, quality control and insurance process. Loan seeker promises to buy the goods as it is from financier under Murabaha contract. This feature of asset based Murabaha contract would literally transfer all risk associated with transaction to loan seeker.

Shair'ah compliance issues relating to several aspects of asset based Murabaha and above mentioned criticism has been subject of inquiries to Islamic Fiqh Academia. For example, the issue related to promise of loan seeker to buy back from financier was subject of Islamic Fiqh Academia Resolution No: 40-41 (2/5 \& 3/5), by which it highlights that "According to Shari'ah, a promise (made unilaterally by the purchase orderer or the seller), is morally binding on the promisor" (Note 2). Regardless of debates on above mentioned aspect of asset based Murabaha sale, Murabaha sale as practices according to FAS-2 is Shari'ah compliant assuming that late payment charges are transferred to a $\operatorname{Waqf}$ (Charity) Fund. After decades it can be deemed as a mature contract now.

Although Murabaha sale is Shair'ah compliant, above mentioned criticisms are valid and can direct industry for implementation of much pleasant structures such as asset backed Murabaha. Asset backed Murabaha can address, though not truly, above mentioned four criticisms in certain degree. In a nutshell asset backed Murabaha is cash and carry financing in which financier would hold the ownership of goods in a storage facility until final sale to loan seeker. In this regard, it is similar to commodity pledge financing of conventional banks. Indeed, many conventional finance products can redrafted to meet Shari'ah compliance (Beck, Demirguc-Kunt, et al., 2010). Under asset backed Murabaha, unlike pledge on commodity as practiced by conventional banks, direct ownership of financier would be needed. Figure-1 briefly explains a transaction flow in an asset backed Murabaha financing in a case of sugar refinery as loan seeker which promise to purchase sugar brought to warehouse from financier.

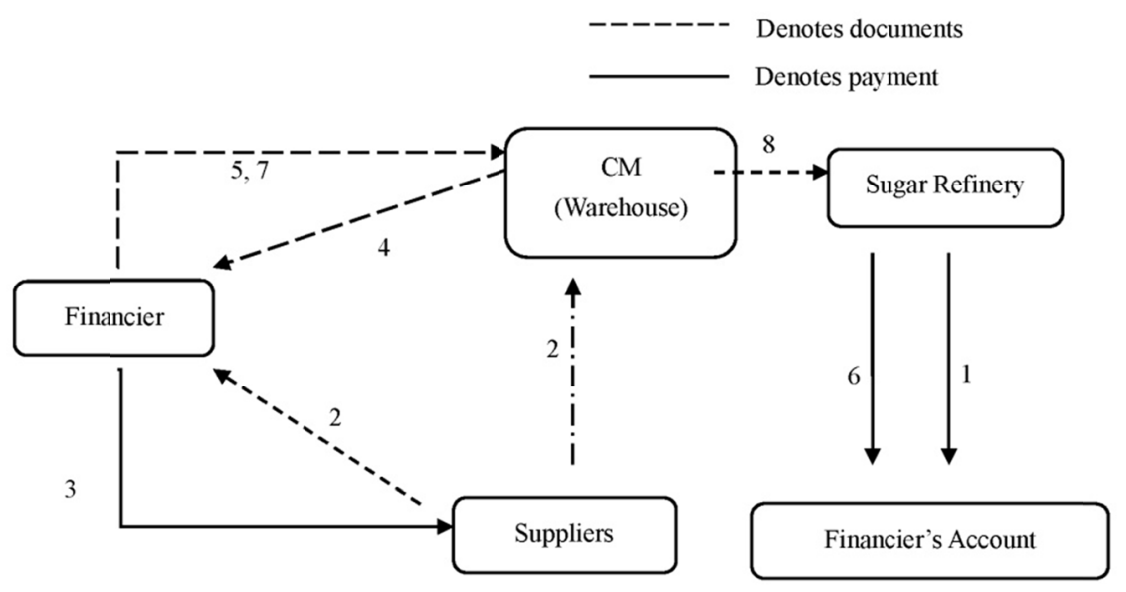

Figure 1. Schematic flow of the transaction

i. Sugar Refinery pays $15 \%$ of the invoice into Financier's Account.

ii. Sugar is shipped and shipingdocuments are presented.

iii. Financier pays the supplier for the raw sugar.

iv. Raw sugar is delivered to the Sugar Refinery's warehouse under Collateral Management. Colletaral Manager issues Warehouse Receipt to Financier.

v. Against Sugar Refinerys request for release of raw sugar, Financier will instruct Colletaral Manager to custody of refined white sugar (as per the conversion factor of 93\%). Upon having the custody of refined sugar, Financier will release the raw sugar for refining.

vi. Sugar Refinery requests release of refined white sugar and pays into the Financier's account.

vii. Financier sends release instruction to Colletal Manager for release once payment is received.

viii. Sugar Refinery takes delivery of refined sugar. 
Once Financier receives the documents for payment, it will ensure that the 15\% deposit margin is in Financier's Account before making payment for the invoice. Financier reserves the right to increase the deposit margin to $25 \%$ if deemed necessary depending on market conditions and expectations on prices. Financier will ensure that the $85 \%$ to be funded which gives it a minimum of $117.6 \%$ security margin against current market prices before making any disbursement. The documents will then be instructed to be delivered to the Collateral Manager who will await delivery of the shipment. The CM will ensure the goods are transported safely from the port to the warehouse where the weight of the raw sugar is verified. Once in custody of the $\mathrm{CM}$, the $\mathrm{CM}$ will issue a Warehouse Receipt in the name of Financier.

When Sugar Refinery requires the raw sugar for refining, they will request Financier for release of the raw sugar. Financier will instruct the CM to take custody of equal quantity of refined sugar before releasing any raw sugar for refining. (The conversion rate is $93 \%$ of raw sugar, i.e. 1000 tons of raw sugar will give 930 tons of refined white sugar). Hence the refined white sugar will under the collateral management until Sugar Refinery requests for release of the same. Financier will invoice Sugar Refinery on the volume requested with corresponding mark-up and line management fee. A copy of the invoice will be sent to Sugar Refinery and once payment is received in Financier's account, the release instruction will be given by Financier.

Unlike asset based Murabaha, asset backed Murabaha necessitate certain level of knowledge on commodity financed since ownership would be staying with financier to constitute collateral. In its basic form such knowledge would include nature of the commodity, global and local regulation such as WTO agreements, quotas, etc., production and consumption figures, major importers and exporters and most importantly price indexes. Assuming ownership of the commodity during transaction would expose financier with certain risks. Hence, necessitates sound risk management practices.

\section{Risk Management}

The success or failure of structured trade finance facilities, asset backed Murabaha structures can be categorized within, is related to proper identification of risk and managing these risks (MacNamara, 2008). In above mentioned structure there are four risk areas: Country, Company, 3rd Party and Commodity related risks. The risk matrix and mitigants for risk management provided in the Annex-1. Gundogdu (2012) provided extensive insight on these aspects of asset backed Murabaha and provided mitigants for managing those risks. For the issue of commodity price risk, he proposed cash deposit, yet, he did not propose a methodology for calculation of cash deposit ratio. Out of these four risk areas, commodity related risk; particularly commodity price risk management has pivotal role in successful implementation of asset backed Murabaha. In case of conventional financing there have been many studies on the nature of the risk and methods to handle risk associated with volatile commodity prices (Claessens \& Duncan, 1993). Unlike conventional finance, Islamic financial intuitions are not able to recourse to most of the methods proposed due to Shari'ah constrains. Since Islamic financier would rely on ownership of the commodity financed as collateral and any decrease in value of collateral may give rise to substantial losses. Collateral damage is another important aspect, yet, the issue related to damage of collateral including misappropriation, accidents or deterioration in quality of commodity during storage can be mitigated with Takaful, Islamic Insurance.

As mentioned, hedging against commodity price risk with derivative instruments is not a possibility since derivative instruments such as forward, futures or options are not Sharia'ah compliant. Hence, developing methods and protocols for managing commodity price risk is most needed to propose asset backed Murabaha as an alternative Islamic finance product. In practice, financier relies on cash deposit from loan seeker as illustrated in Figure 1. The cash deposit percentage usually changes from $15-25 \%$ depending on personal judgment regarding price volatility of commodity financed. The more volatile the price appears, the higher the cash deposit requested. However, there is no scientific methodology for calculating cash deposit margin. The cash deposit margin to be asked should change not only by commodity but also tenor of financing since longer tenor might expose financier to higher price volatility. Figure 2 compares last 30 years sugar prices. 


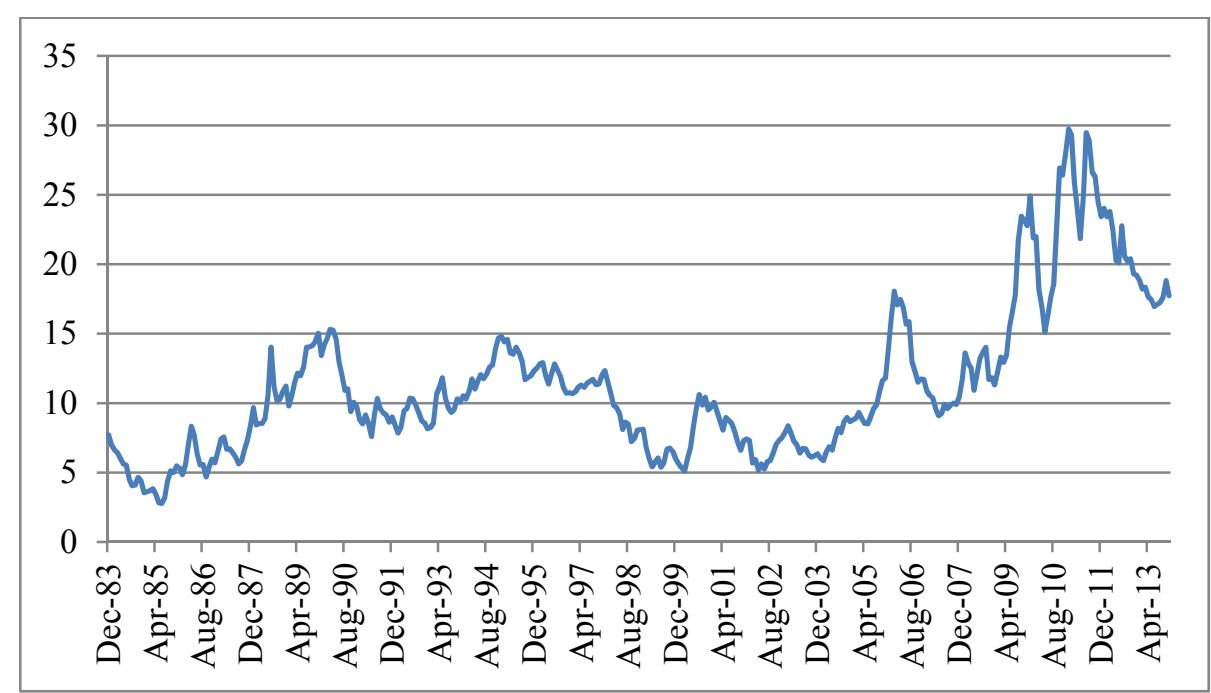

Figure 2. Sugar, free market, coffee sugar and cocoa exchange (CSCE) contract no.11 nearest future position, US cents per pound

Source: NYMEX-CME Group.

By looking at Figure-2, it is possible to discern pattern, yet, percentage of cash deposit to be asked for sugar financing under asset backed Murabaha needs further processing of data.

\section{Security Margin Calculation and Margin Call}

If we look at the descriptive statistics for one month price change for last 30 years, as presented in Table- 1 , on average sugar prices increased by $0.6 \%$ with standard deviation of $8.7 \%$ and minimum observation of $-22.3 \%$. Deducting standard deviation of $8.7 \%$ from average, would give a risk managed security coverage ratio of $-8.1 \%$ though in worst case, sugar prices went down by $22.3 \%$ in one month tenor.

Table 1. Descriptive Statistics for one month sugar price change

Source: Calculated by the author.

\begin{tabular}{lr}
\hline Mean & 0.006039 \\
\hline Standard Error & 0.004609 \\
Standard Deviation & 0.087322 \\
Sample Variance & 0.007625 \\
Kurtosis & 1.144287 \\
Range & 0.6035 \\
Minimum & -0.223 \\
Maximum & 0.3805 \\
Sum & 2.1681 \\
Count & 359 \\
\hline
\end{tabular}

Is $-8.1 \%$ the cash deposit to be asked for one month tenor for asset backed Murabaha? Indeed, $8.1 \%$ should be named as security coverage ratio. In case of $15 \%$ cash deposit as illustrated in Figure 1, security coverage ratio is $117.64 \%((100 / 85) \%)$. Let's assume financier holds ownership of 1 pound of sugar worth $\$ 1$ and paid only $\$ 0.85$ to assume such collateral. The cost of sugar for financier is $\$ 0.85$ per pound; the market price is $\$ 1$ per pound. For any decrease to eat up $\$ 0.15$ cash deposit, price needs to go down $\% 17.64$ from $\$ 0.85$ to $\$ .70$. Accordingly, to have $8.1 \%$ security coverage as calculated from mean and standard deviation, financier should be asking for $7.5 \%$ cash deposit $(8.1 \%=7.5 \% /(100 \%-7.5 \%)$.

Cash Deposit would be calculated from Security Coverage ratio as indicated in Equation-1:

$$
\text { Cash Deposit }=(100 * \text { Security Coverage Ratio }) /(100+100 * \text { Security Coverage Ratio })
$$




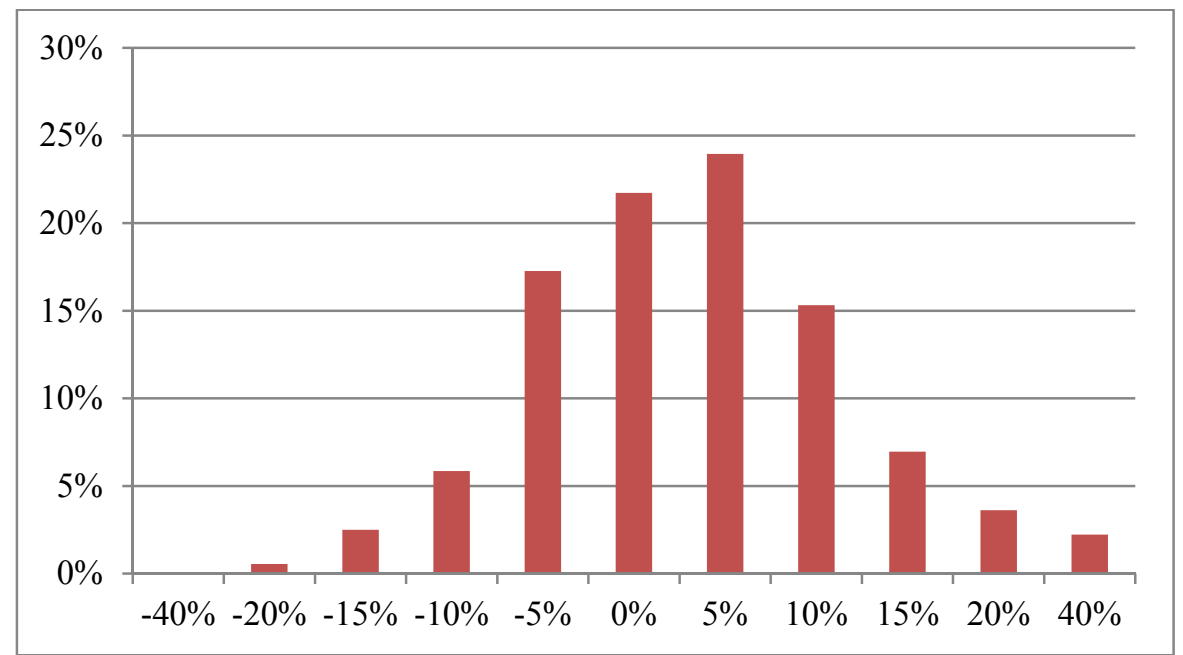

Figure 3. Histogram for one month sugar price change

Cash deposit, hence, security coverage ratio needed for risk management would change based on tenor: the longer the tenor, the higher cash deposit needed. Table 2 indicates descriptive statistics, cash deposit and security coverage ratio for three months, six months and nine months tenors. Security coverage ratio is calculated by subtracting standard deviation from mean.

Table 2. Descriptive statistics, security coverage and cash deposit needed for 3-6-9 months tenor financing

\begin{tabular}{lrlllr}
\hline \multicolumn{2}{c}{ 3 Months Tenor } & \multicolumn{2}{c}{ 6 Months Tenor } & \multicolumn{2}{c}{ 9Months Tenor } \\
\hline Mean & 0.02318 & Mean & 0.047556 & Mean & 0.073397 \\
Standard Error & 0.009758 & Standard Error & 0.014122 & Standard Error & 0.017636 \\
Standard Deviation & 0.18438 & Standard Deviation & 0.265695 & Standard Deviation & 0.330408 \\
Sample Variance & 0.033996 & Sample Variance & 0.070594 & Sample Variance & 0.10917 \\
Kurtosis & 2.043237 & Kurtosis & 0.978302 & Kurtosis & 2.4579 \\
Range & 1.17546 & Range & 1.370449 & Range & 2.086337 \\
Minimum & -0.33373 & Minimum & -0.38914 & Minimum & -0.46684 \\
Maximum & 0.841727 & Maximum & 0.981308 & Maximum & 1.619497 \\
Sum & 8.275393 & Sum & 16.83491 & Sum & 25.76241 \\
Count & 357 & Count & 354 & Count & 351 \\
Security Coverage needed & $16.12 \%$ & Security Coverage needed & $21.81 \%$ & Security Coverage needed & $25.70 \%$ \\
Cash Deposit needed & $13.88 \%$ & Cash Deposit needed & $17.91 \%$ & Cash Deposit needed & $20.45 \%$ \\
\hline
\end{tabular}

Source: Calculated by the author.

Although standard deviation is proposed as pivot in calculations, since margins are considered for only downward trends but not price increase, rank and percentile methodology may give another indication. For example, in Figure 3, the histogram, interest is in observations on the left side of $0 \%$ since any increase in sugar prices will increase security coverage ratio, hence, not subject of risk management surveillance. Figure 4 indicates rank and percentile for six month tenor. From standard deviation, security coverage margin calculated as $21.81 \%$. From rank and percentile, in 5 percent confidence interval, security coverage would be calculated as $28.66 \%$. Rank and percentile calculation can be labeled as more conservative methodology without prejudicing the merit of standard deviation calculation. 


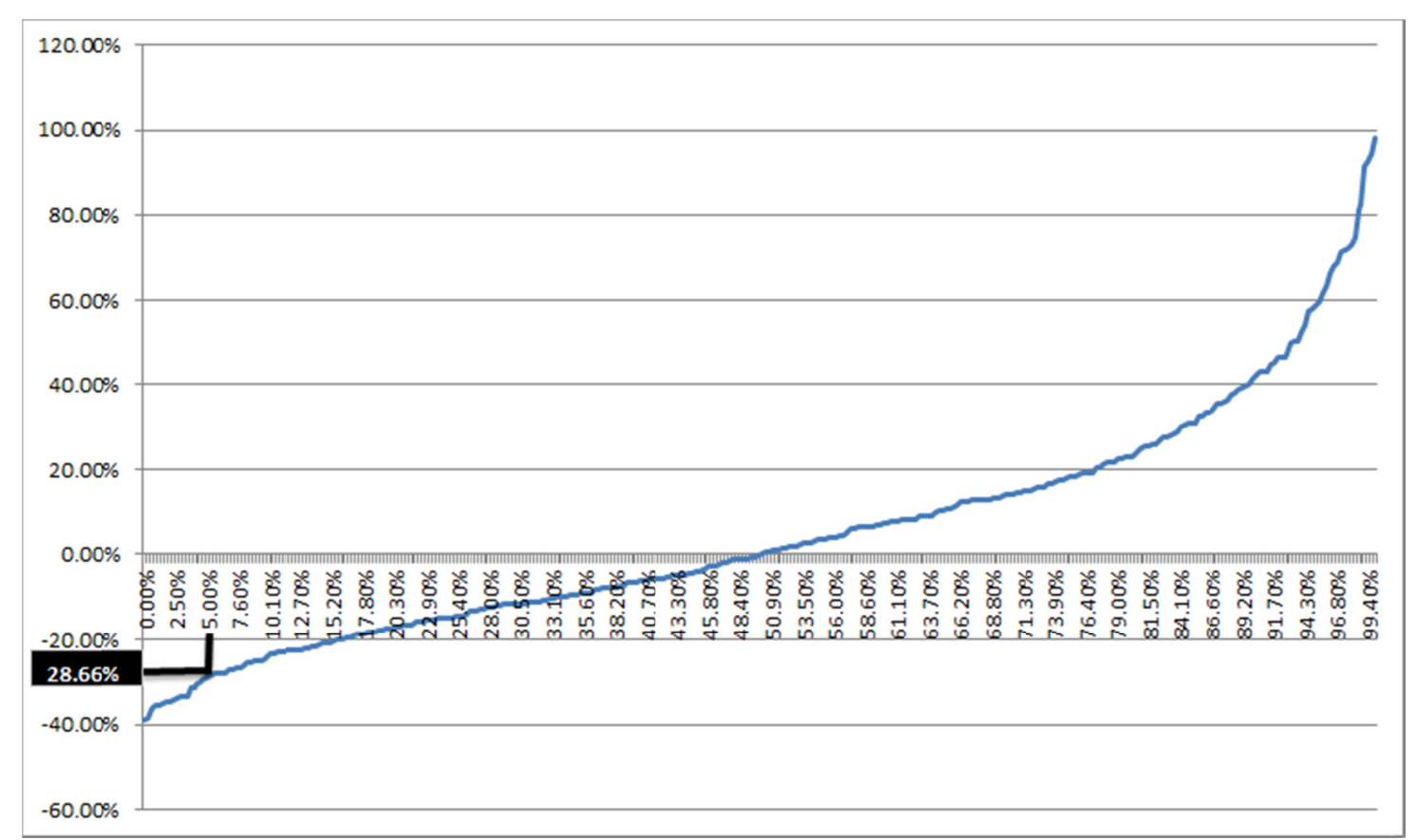

Figure 4. Rank and percentile for six month sugar price changes

It is already mentioned that Islamic financial institutions are not able cover themselves with derivative hedging contract due to Shair'ah compliance restriction. Similarly, they cannot just get cash deposit and rely on it until loan maturity. Any decrease in commodity prices would give rise to collateral damage and expose financier to risk. Hence, Islamic financial institutions need to manage their risk during the financing period by following up security coverage margins daily, and ask borrower to keep pre-agreed security coverage ratio by toping-up with either money or commodity: margin call if needed. Indeed, this is very much in compliance with Islamic finance philosophy which urge financier to assume risk in exchange of expected profit. Nevertheless, as expected from any actor in economy, Islamic financial institutions should also be prudent in their risk taking practices. An example of exercising margin call presented in Table 3 for a six month tenor financing which disbursed on January 2012. Guidelines for margin call can differ from institutions to institutions and should be tailor made for structure of financing facility, commodity, geographic region, etc. For illustration purposes, following guidelines assumed for calling margins in case of 6 months tenor:

i. A decrease in commodity price by $5 \%$ in three days;

ii. A decrease in commodity price by $8 \%$ in 1 month;

iii. A decrease in commodity price by $10 \%$ in 2 month;

iv. A decrease in commodity price by $12 \%$ in 3 months;

v. A decrease in commodity price by $14 \%$ in 4 months;

vi. A decrease in commodity price by $16 \%$ in 5 months.

Table 3. Margin call illustration for six month tenor financing

\begin{tabular}{rccccccc}
\hline Month & $\begin{array}{c}\text { Price, US cents } \\
\text { per Pound }\end{array}$ & $\begin{array}{c}\text { Change in } \\
\text { 1 month }\end{array}$ & $\begin{array}{c}\text { Change in } \\
\text { 2 month }\end{array}$ & $\begin{array}{c}\text { Change in } \\
\text { 3 month }\end{array}$ & $\begin{array}{c}\text { Change in } \\
\text { 4 month }\end{array}$ & $\begin{array}{c}\text { Change in } \\
\text { 5 month }\end{array}$ & $\begin{array}{c}\text { Change in } \\
\text { 6 month }\end{array}$ \\
\hline Jan-12 & 24.02 & $2.56 \%$ & $-2.04 \%$ & $-8.67 \%$ & $-9.83 \%$ & $-16.80 \%$ & $-18.49 \%$ \\
Feb-12 & 23.42 & $-2.50 \%$ & $0.00 \%$ & $-4.49 \%$ & $-10.95 \%$ & $-12.09 \%$ & $-18.88 \%$ \\
Mar-12 & 23.79 & $1.58 \%$ & $-0.96 \%$ & $1.58 \%$ & $-2.98 \%$ & $-9.54 \%$ & $-10.70 \%$ \\
Apr-12 & 22.48 & $-5.51 \%$ & $-4.01 \%$ & $-6.41 \%$ & $-4.01 \%$ & $-8.32 \%$ & $-14.52 \%$ \\
May-12 & 20.27 & $-9.83 \%$ & $-14.80 \%$ & $-13.45 \%$ & $-15.61 \%$ & $-13.45 \%$ & $-17.33 \%$ \\
Jun-12 & 20.1 & $-0.84 \%$ & $-10.59 \%$ & $-15.51 \%$ & $-14.18 \%$ & $-16.32 \%$ & $-14.18 \%$ \\
Jul-12 & 22.76 & $13.23 \%$ & $12.28 \%$ & $1.25 \%$ & $-4.33 \%$ & $-2.82 \%$ & $-5.25 \%$ \\
\hline
\end{tabular}

Source: Calculated by the author. 
At the date of disbursement in January 2012, sugar price registered as 24.2 cent and commodity held to maturity until July 2012. Ending price registered as 22.76 cent. If the commodity held for six month, value would decrease only by $5.25 \%$. Since a cash deposit of $17.91 \%$ received from borrower before disbursement in January 2012, there would be no breach of security coverage ratio. Nevertheless, as per assumed guidelines, borrower would need top up in May and June 2012. Note that even though margins are called in May and June 2012, cash deposit calculated as $17.91 \%$ sufficed for enough security coverage during financing period. Besides, in real life, loan seeker would ask for release of sugar regularly for processing throughout six month and very few of sugar if not at all would stay in warehouse at the end of six months. This would decrease the value at risk.

\section{Discussion and Conclusion}

Although very much criticized, there are much role to be played by asset based Murabaha as practiced in accordance with "FAS-2: Murabaha and Murabaha to the Purchase Orderer" standard developed by Accounting and Auditing Organization for Islamic Financial Institutions. Even in its basic form, Murabaha contracts relate financing with genuine economic transactions and have relatively less potential to create liquidity bubble. Asset backed Murabaha, as example introduced in this work, can also render substantial service given that Islamic financial institutions know how to manage risk associated with holding ownership of commodity financed during the tenor of financing.

On the other hand, similar to asset based, asset backed Murabaha contracts are not immune from criticisms and such criticisms should be well received to carry Islamic finance industry to healthier frontier. Major criticism might be expected on cash deposit, which are not paid in case of default to loan seeker, in asset backed Murabaha. Ahmad (2010), argues that such practice may not be compliant with Islamic Shair'ah which prohibit contractual penalty (Note 3). Nevertheless, in case of day to day business one may ask for down payment and may or may not returns back the down payment if promisor does not fulfill its promise. Although analogy is not the favorite of Islamic Fiqh: a landlord may ask for down payment from a potential purchaser of a real estate so he does not miss the opportunity of selling the property to another person if potential purchaser changes his mind If such practice is Shair'ah compliant for individuals, why should it not be for Islamic financial institutions? At the end, Islamic Shari'ah is applicable uniformly.

Above developed security coverage methodology as risk management tool may not hundred percent cover possible losses but at least it can stop losses at a certain level by margin calls and market monitoring. At the end, Islamic finance philosophy neither proposes risk free return nor excessive and uneducated risk taking. Managing price risk as subject of this study is only one aspect of risk management under asset backed Murabaha. There are some other aspects concerning to ensuring and sustaining healthy ownership of commodities which requires extensive commodity knowledge, working with third parties such as collateral management companies, insurance brokers, warehouse operators, etc. This course of Islamic finance practice, asset backed, would necessitate extensive due diligences and converge Islamic finance to genuine transaction and improve their technical capacity. Hence, Islamic banks can play their role as investment agents for saving account holders and facilitator to grease the wheel of economy by providing needed funds for genuine, sensible and solid transactions.

\section{References}

Ahmad, A. U. F. (2010). Theory and Practice of Modern Islamic Finance: The Case Analysis from Australia. Florida, USA: Brown Walker Press.

Beck, T., Demirguc-Kunt, A., \& Merrouche, O. (2013). Islamic vs. conventional banking : Business model, efficiency and stability. Journal of Banking \& Finance, 37(2). http://dx.doi.org/10.1016/j.jbankfin.2012.09.016

Claessens, S., \& Duncan, R. C. (1993). Managing commodity price risk in developing countries. Baltimore: Johns Hopkins University Press.

Gundogdu, A. S. (2012). Developing Islamic Finance Opportunities for Trade Financing: Essays on Islamic Trade Vis-à-Vis the OIC Ten-Year Programme of Action. UK: Doctoral dissertation, University of Durham.

Gundogdu, A. S. (2009). 2-Step Murabaha as an Alternative Resource Mobilization Tool for Islamic Banks in the Context of International Trade. International Journal of Monetary Economics and Finance, 2(3/4). http://dx.doi.org/10.1504/IJMEF.2009.029064

Hasanin, F. (1996). Murabaha Sale in Islamic Banks. Virginia, USA: The International Institute of Islamic Thought. 
IFSB, I. F. (2005). Guiding Principles of Risk Management for Institutions (Other than Insurance Institutions) Offering only Islamic Financial Services. Kuala Lumpur, Malaysia: IFSB.

Khan, T. (2001). Risk Management: An Analysis of Issues in Islamic Financial Industry. Jeddah, Saudi Arabia: Islamic Research and Training Institute.

MacNamara, J. (2008). Structured Trade and Commodity Finance: What Can Go Wrong and How to Avoid It. Cambridge, UK: Woodhead Publishing Limited.

The Accounting and Auditing Organization for Islamic Financial Institutions. (1997). Financial Accounting Standard No. 2 (FAS 2) Murabaha to the Purchase Orderer. Manama, Bahrain: AAOIFI.

Vogel, F. E., \& Hayes, S. L. (1998). Islamic Law and Finance: Religion, Risk and Return. The Hague, Netherlands: Kluwer Law International.

Yousef, T. M. (2004). The Murabaha Syndrome in Islamic Finance: Laws, Institutions and Politics. In R. Wilson (Ed.), The Politics of Islamic Finance (pp. 63-80). Edinburgh: Edinburgh University Press. http://dx.doi.org/10.3366/edinburgh/9780748618361.003.0003

\section{Notes}

Note 1. See Ahmad, A. U. F. (2010). Theory and Practice of Modern Islamic Finance: The Case Analysis from Australia (pp. 199-202). Florida, USA: Brown Walker Press.

Note 2. Available at http://www.irtipms.org/PubText/73.pdf, Pp.86-87, last accessed on 10/01/2014.

Note 3. See. Pp. 200. Ahmad, A. U. F. (2010). Theory and Practice of Modern Islamic Finance: The Case Analysis from Australia. Florida, USA: Brown Walker Press.

\section{Appendix A.}

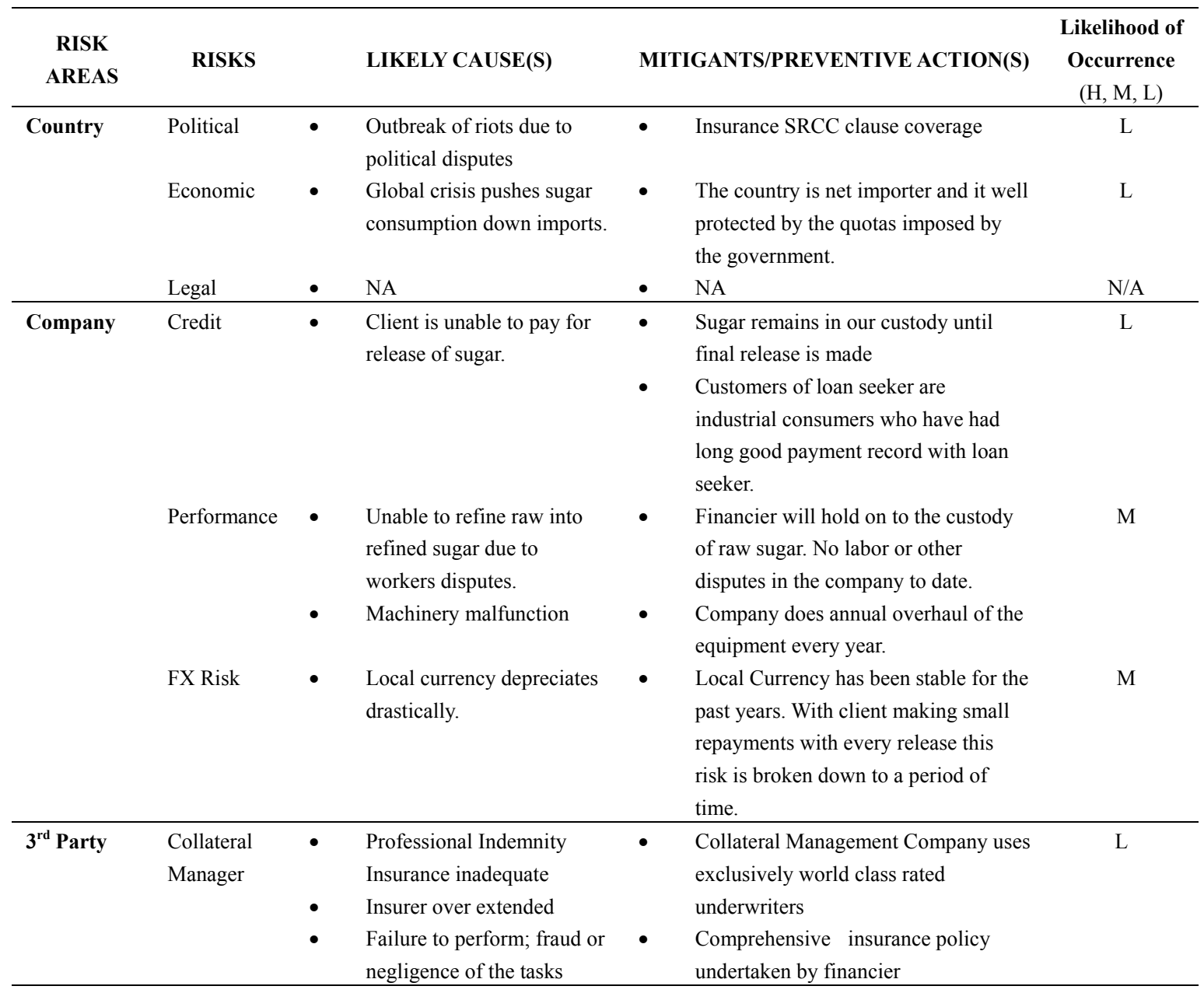




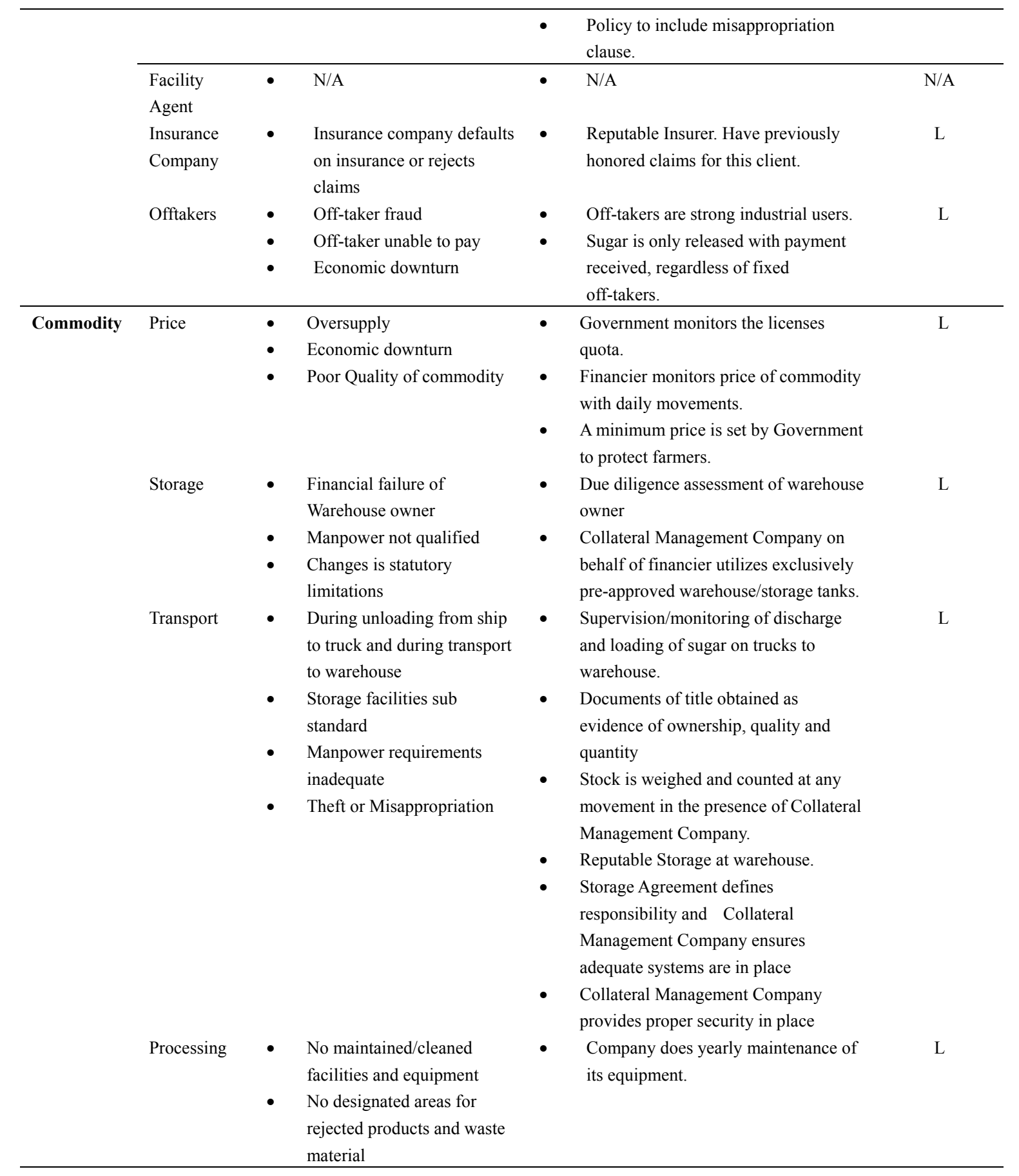

Source: International Islamic Trade Finance Corporation.

\section{Copyrights}

Copyright for this article is retained by the author(s), with first publication rights granted to the journal.

This is an open-access article distributed under the terms and conditions of the Creative Commons Attribution license (http://creativecommons.org/licenses/by/3.0/). 